\title{
Effect of Goat Production to the Environment in the Humid Tropics of the World
}

\author{
S.I. Ume ${ }^{1, *}$, C.I. Ezeano ${ }^{2}$, P.C. Jiwuba ${ }^{3}$ \\ ${ }^{1}$ Department of Agricultural Extension and Management, Federal College of Agriculture \\ Ishiagu, Ivo Local Government Area of Ebonyi State, Nigeria \\ ${ }^{2}$ Department of Agricultural Economics and Extension, Nnamdi Azikiwe University, \\ Awka, Anambra State, Nigeria \\ ${ }^{3}$ Department of Animal Production Technology, Federal College of Agriculture Ishiagu, \\ Ivo Local Government Area, Ebonyi State, Nigeria
}

umesmilesi@gmail.com

Keywords: Effect, Goat, Production, Environment, Humid Tropics, World.

\begin{abstract}
The research was aimed at identifying the determinants of goat farmers' choice of adaptation methods to climatic change in Southeast Nigeria. The specific objectives of the study were to identify the farmers' adaptation methods, identify the determinants of choice of the adaptation methods, the limiting factors to farmers' adaptation options in the study area. A total of 120 farmers were selected using multistage random sampling technique. Data were collected using a structured questionnaire. The data were analyzed using descriptive statistics such as percentage responses and multinominal logit model and factor analysis. The adaptation strategies used by the goat farmers were use of nutrient-dense diets, drinking water, planting of tree as shade and location of house in the farm. Additionally, the effects of goat production to the environment were deforestation, land degradation, climate change, air pollution and rodent menace. In addition, goat Production technologies to curtail environmental pollution were precious feed management, litter management, use of hydrophilic products, use of rat poison and trap, adequate housing and proper manure disposal. The factors influencing farmers' choice of adaptation methods were level of education, membership of cooperative, farming experience, poor access to extension services and access to credit. The determinant factors to the adoption of goat production-related environmental technologies were level of education, extension visit, off-farm income, farming experience and membership of organization. The result also showed that the major factors limiting factors to adoption of the technologies were poor access to funds, poor access to improved technology and poor access to heat resistant goat breed. There is a need to enhance farmers' access to credit, extension services and educational programs.
\end{abstract}

\section{Introduction}

Globally, goat population was estimated at 76 million with more than 53.2 million from developing countries [1]. Nigeria has about 24 million goats, representing about $4 \%$ of the current world population [2]. The importance of goat production boosting global food security cannot be overemphasized. Goat helps to boost global kilocalorie consumption and protein consumption, contributes to the livelihoods and source of employments for the people, creating new employment opportunities in the industrial and service sectors, increasing external trade [3], used for religious and cultural rituals, improvement of soil fertility through its dung, for hide and skins and insurance for saving against adverse conditions [4]. Goat production is endeared to mostly small holder farmers in sub Saharan Africa through possession of certain attributes over many small livestock, lower cost of production, ability to utilize poorer quality forages to meat, milk and hide, browsers of wide range of forage and require comparatively fewer resources such as labor and buildings [5]. Furthermore, chevron is lower in calories, total fat and saturated fat compares to other livestock meat, higher in protein and easily digestible $[6,7]$.

The environmental benefits of goat production are well documented [2, 3, 7]. The gains according to [6] include keeping wildlife corridor open, avert the propagation of poisonous weeds, 
and encourage the growth of local vegetative species through reasonable grazing and more waterefficient than other ruminants. On the other way, its effects on the environment are causing concern to policy maker, program planners and the government [6]. For instance, studies $[4,6,8]$ revealed that domesticated ruminant, goat inclusive is responsible for climate change through release of $37 \%$ of methane and about $65 \%$ of nitrous oxide gases derived from their manure [3]. Nevertheless, these actions of the animals are in conjecture with man - related activities resulting in emission of $9 \%$ of all carbon dioxide [9].

This important domestic animal existence is being threatened with all swiftness by climate change in order to deepen the poverty web that is often associated with the goat farmers. Climate change as asserted by [10] is due to an increase in temperature and atmospheric carbon dioxide (CO2) concentration, precipitation variation, and a combination of these factors. The severity of the effects of the causative agents of climate change varies but literature show that farmers in developing countries are most vulnerable because of their low level of coping capabilities as result of poverty and illiteracy [11].

However, the effects of climate change on goat production vary significantly depending on the weather elements concerned. Studies show that at temperature range of $13-18^{\circ} \mathrm{C}$, relative humidity of $50-60 \%$ and low wind level are the optimum environmental requirements for goat production (Wilson, 2004). Hence, any alteration of these requirements could tantamount to undesirable conditions that are capable of affecting the health and welfare of the animal. For instance, the increase in temperature to more than the upper critical temperature range (above $90^{\circ} \mathrm{F} / 32.2^{\circ} \mathrm{C}$ ), is capable of causing heat stress to the animal with the resultants effects of reduction in feeding, reproduction (lack of libido and affects semen development in the male animal), less tolerant to diseases and opportunistic infestation, detrimental to embryo survival and fetal development and death at critical stage $[12,13]$. Furthermore, high temperature is often associated with the growth of pathogens and/or parasites that are inside and outside the hosts [7], while at lower temperature, risk of acidosis or bloat could result as the animal feeds on early morning forage [14]. Reported on global warming and changes in precipitation, [12] reported that the variability of the weather elements are capable of affecting the quantity and spread of vector-borne pests such as flies, ticks, and mosquitoes in goat production. Also, Kanes and Tobenyi, (1992) reveals that wind helps in ensuring proper ventilation of the animal pen in order to evade odour and disease and pests building up, but in contrast destroy animal pen. [15] in their study opined that high relative humidity is a potential to reduction of the animal feed intake and building up of pests and diseases in goat pen. The indirect effects of climate change in goat production is capable resulting in longevity of endemic species health, low productivity, availability of feed from byproducts due to change in priorities, increase in cost of production [16] changes in geographical distribution of trade regime, increased number of people at risk of hunger and food insecurity, migration, civil unrest and reduce market options [17, 18].

However, apart from climate change, other effects of goat production to environment are well recognized. The impact of goat production in air and pollutions contribution is well documented [4, $7,10]$. A case in point, mismanagement of litters in goat production is capable of fleeting the goat production environment with odour through its manure, rat proliferation and other nuisance, including flies, and mosquitoes breeding, which might predispose victims to varied ill health such as malaria, typhoid and others [10]. Also, such air pollution might result in respiratory diseases, catarrh, blurred vision, depression, asthma, and nerve damage to the casualty [7]. Besides, the seepage of by product of goat such as manure into the water bodies is capable of living toxic effect on the ecosystem. Studies $[2,11]$ show that such scenario could result to varied health risks to man, including cholera, dysentery cancer, diarrhea birth defects, neurotic and immunological disorder, reproductive abnormalities, vomiting, abdominal pain, suppress the immune system, lead to blood and liver diseases [5, 11]. As well, such water pollution could lead to eutrophication, hence altering the natural vegetation, fauna and flora and excess algal growth. The water in question is unsafe for human consumption because it is decolourized and infested with odour and toxic to aquatic fish [4]. Furthermore, land degradation as caused by goat through its especially hard and sharp hoofs which pulverize the soil has been a persistent problem in many sub Saharan society and a serious impediment to long-term development 
in recent time $[2,14]$. The impact of land degradation apart from physical, chemical and biological degradation, there is a loss of employment opportunities with migration and its aftermath as the consequent. Furthermore, land degradation may possibly lead to the destruction of ecosystems and the extinction of wildlife [3,7]. The negative impacts of activity are enormous, including food production, livelihoods, and the production and provision of other ecosystem goods and services [14]. In addition, goat grazing could be beneficial in terms of ecological, silvicultural and economic but the uncontrolled goat grazing may lead to deforestation, with resultant effects of loss of habitat for millions of species. Nevertheless, the the impact of the animal to this process depends on flock size, levels of free range and grazing method [69].

Therefore, there is a need to develop mechanism of alleviating these farmers from this peril of climate change in order to circumvent the possible extinction of this animal. This could be remedied through adoption of adaptation coping strategies. Adaptation entails the use of risk minimizing strategies and adoption of innovative low-input practices that can adapt to the environmental change [19]. Globally, farmers both in developed and developing countries have developed adaptation coping strategies to climate change through deep understanding of farming systems and experience, use of traditional knowledge and traditional systems that are suited to their particular environments [20]. Studies show that in many developing countries of Africa, goat farmers have varied forms of adaptation coping strategies to climate change which are often location and farmer specifics ( Inter-Governmental panel on Climate Change [21]. The commonly adaptation coping strategies are destocking, provision of sunshade, adequate ventilation, use of drought resistant breeds, use of raised plank form, extensive rearing of the animals and improved nutritional management $[16,22]$. The adoption of the choice of different adaptation strategies to climate change are affected by a host of socioeconomic and environmental factors [18, 23].

[22] in their study in Nile basin of Ethiopia, reported that credit constraints, poor extension outreach and farm size were the determinants of farmers' choice of adaptation methods to climate change. In the same vein, [24] found educational level, level of knowledge of climate change, household size and membership of cooperatives to had affected his respondents' choice of adaptation coping strategies in Kenya. Nonetheless, through research various innovations have been invented with anticipation of curtailing the aforesaid environmental scenario menace apart from climate change, including precious feed management, litter management, use of hydrophilic products, Adequate housing, proper disposal of animal carcass and proper manure disposal [1, 2]. The accomplishment of these technologies in curbing the environment effects of goat production in many developed countries is well recognized, but mixed feelings in most developing countries, Nigeria inclusive.

In Nigeria, studies abound on the farmers' perception of effects of climate change on production and climatic adaptation strategies on crops and animals $[25,26]$. But to the best of the knowledge of the researcher, no known published work on the factor saffecting the choice of the adaptation coping strategies to climate change, the extent of adoption of goat production technologies in order to abate its effects to environment and in the study area. Therefore, such information could assist policy makers to strengthen adaptation efforts through investing in the factors.

Specifically, the objectives are:

i describe the socio economic characteristics of the respondents;

ii identify the adaptation strategies adopted by the farmers'

iii identify the effects of goat production to the environment;

iv identify goat production technologies used to abate environmental effects;

$\mathrm{v}$ analyze the effects of farmers' socio-economic characteristics on their rate of adoption of technology

vi determine the climatic change adaptation options adopted by the farmers and

vii determine the rate of adoption of goat production technologies in order to abate its effects to environment in the study area 


\section{Materials and Methods}

The South East Nigeria was the study area and it lies between latitude $5^{0} 69^{\prime}$ and $7^{0} 75^{\prime} \mathrm{N}$ of equator and longitude $6^{0} 85^{\prime}$ and $8^{0} 46^{\prime}$ East of Greenwich Meridian. It has a total land mass of 10,952.400 ha and population of 16,381.729 people [27]. The zone is made up of five states viz: Abia, Anambra, Ebonyi, Enugu and Imo. The zone is bordered in the North by Benue and Kogi States, in the West by Delta and Rivers States, in the South by Akwa Ibom State and in the East by Cross River State. Southeast states have two major seasons in the year, the rainy season (April - October) and dry season (November to March). It has temperature range between $18^{0} \mathrm{C}-34^{\circ} \mathrm{C}$ and relative humidity of $60-70 \%$. The inhabitants are agrarian and still engage in other none farm activities for sustenance.

A multi-stage random sampling technique was used to select states, Local Government Area (LGA), communities, village and respondents. In the stage I, four states were randomly selected out of five. . In stage II, three LGAs each were selected from each of the four states. This brought to a total of twelve Local Government Areas. In the third stage, ten towns each were randomly selected from each of the LGAs. This brought to a total of one hundred and twenty towns. In the third stage, one village each was randomly selected from each of the one hundred and twenty towns. Finally, with help of local leader and Agricultural Development Programmed (ADP) extension agents, the lists of goat farmers in the selected villages were made available. From the list, one farmer was randomly selected from the selected towns. This brought to a total of one hundred and twenty goat farmers for detailed study.

A structured questionnaire was used to collect information on primary data, while secondary data was obtained from literatures, journals, proceedings, textbooks and other periodicals. Descriptive statistic such as percentages and frequency distributions was used to address objectives I and ii. Objective iii was addressed using Multi Nominal Logit Model (MNLM), while factor analysis was used to address objective iv.

\section{Multi-Nominal Logit Model (MNLM)}

According to Magombo et al. [24], MNL model for choice of adaptation strategies specifies the relationship between the probability of choosing an adaptation option and the set of explanatory variables. The adaptation strategies are grouped into six groups, since the households use more than one strategy and one group is "no adapting to climate change". Thus the groups are destocking.

The MNL Model is stated implicitly as follows:

$$
\mathrm{Y}_{\mathrm{i}}=\operatorname{In}\left(\mathrm{P}_{\mathrm{i}}, \mathrm{P}_{\mathrm{I}}\right)=\beta_{0}+\beta_{1} \mathrm{X}_{1}+\beta_{2} \mathrm{X}_{2}+\beta_{3} \mathrm{X}_{3}+\beta_{4} \mathrm{X}_{4}+\beta_{5} \mathrm{X}_{5}+\beta_{6} \mathrm{X}_{6}+\beta_{7} \mathrm{X}_{7}+\beta_{8} \mathrm{X}_{8}+\beta_{9} \mathrm{X}_{9}+\mathrm{e}_{\mathrm{i}}
$$

where

$\mathrm{Y}_{\mathrm{i}}=$ adaptation strategy (no adaption; heat tolerant breeds, adequate cross ventilation, adequate and clean water in the war rowing trough, appropriate roofing materials, less fatty food in their feed and any other strategies).

$\mathrm{X}_{\mathrm{i}}$, where $\mathrm{i}=1,2,8$ are explanatory variables,

$\begin{array}{lll}\mathrm{X}_{1}= & \text { Gender of the farmers (Male=1, Otherwise }=0) \\ \mathrm{X}_{2}= & \text { Age of the farmers (Years) } \\ \mathrm{X}_{3}= & \text { Educational attainment (Years) } \\ \mathrm{X}_{4}= & \text { Experience in farming (Years) } \\ \mathrm{X}_{5}= & \text { Availability of Extension Services (Access=1, Otherwise }=0) \\ \mathrm{X}_{6}= & \text { Membership to social network }(\text { Member }=1 \text { Otherwise=0) } \\ \mathrm{X}_{7}= & \text { Access to credit }(\text { Access }=1, \text { non access }=0) \\ \mathrm{X}_{8}= & \text { Access to information }(\text { Access }=1, \text { otherwise }=0) \\ \mathrm{ei} & = & \text { error term }\end{array}$

\section{Model Specification}

The multinomial logit (MNL) model is used to analyze the determinants of farmers' choice of adaptation strategies in South East Nigeria. The advantage of the MNL is that it permits the analysis of decisions across more than two categories, allowing the determination of choice probabilities for 
different categories (20) and it is also computationally simple. Let $\mathrm{x}$ be a $1 \mathrm{x} \mathrm{K}$ vector with first element unity. The MNL model has response probabilities of

where $\mathrm{B}_{\mathrm{j}}$ is $\mathrm{K} \times 1 ; \mathrm{j}=1 ; \ldots ; \mathrm{J}$

$$
\mathrm{P}(\mathrm{y}=\mathrm{j} \mid \mathrm{x})=\exp \left(\mathrm{x} \beta_{\mathrm{j}}\right) /\left[1+\sum_{h=1}^{j} \exp (x \beta \mathrm{h}), \mathrm{j}=1, \ldots, \mathrm{J}\right]
$$

To describe the MNL model, let $Y$ denote a random variable taking on the values $\{1,2, \ldots, J\}$ for $\mathrm{J}$, a positive integer, and let $\mathrm{x}$ denote a set of conditioning variables. In this case, $\mathrm{y}$ denotes adaptation options or categories and $\mathrm{x}$ contain different household, institutional and environmental attributes. The question is how cetirus paribus changes in the elements of $x$ affect the response probabilities $(P(y=j / x), j=1,2, \ldots, J$. Since the probabilities must sum to unity, $P(y=j / x)$ is determined once we know the probabilities for $\mathrm{j}=2, \ldots, \mathrm{J}$.

Unbiased and consistent parameter estimates of the MNL model in Eq. (1) require the assumption of independence of irrelevant alternatives (IIA) to hold. More specifically, the IIA assumption requires that the probability of using a certain adaptation method by a given household needs to be independent from the probability of choosing another adaptation method

\section{Logistic Regression Model}

The Logistic regression model is capable of revealing factors influencing of varied factors on technology adoption and as well forecast the odds of the adoption. The dependent variable is the probability of the farmer using environmental free technologies or not and the logistic regression describing environmental free technologies adoption by the respondents are stated as follow:

$$
\mathrm{Y}(\mathrm{Mi})=\mathrm{K}(\mathrm{Mi})=\mathrm{e} \alpha+\beta \mathrm{Li} / 1+\mathrm{e} \alpha+\beta \mathrm{Li}
$$

$\mathrm{Ki}$ is the chances of the ith farmer with ith features probable to employ the technologies.

$\mathrm{Y}(\mathrm{Mi})+\mathrm{K}(\mathrm{Mi})=1$, where $\mathrm{Mi}=1$ where each farmer utilize the skills 1 and $\mathrm{Yi}=0$, here individual farmer do not use the technologies.

$\mathrm{Xi}$ represents a vector of features that is correlated with the ith individual farmer. $\beta \mathrm{i}$ is the vector of the predictable coefficients. The regression model is linearlized as follows

$$
\operatorname{In}\left(\mathrm{Ki} /(1-\mathrm{Ki})=\beta \mathrm{o}+\beta_{1} \mathrm{~L}_{1}+\beta_{2} \mathrm{~L}_{2} \ldots \beta_{8} \mathrm{~L}_{8}+\varepsilon\right.
$$

The dependent variable is the natural log of the probability of adopting $(\mathrm{P})$ divided by the odd of not adopting it $(1-\mathrm{K})$. $\beta \mathrm{o}$ is the intercept term, and $\beta_{1}, \beta_{2} \ldots \ldots \beta_{8}$ are the coefficients related with each explanatory variable, $\mathrm{L}_{1}, \mathrm{~L}_{2} \ldots \ldots \ldots \mathrm{L}_{8}$.

The hypothesis of the development of the logistic model was supported that a farmer's decision to accept or reject new technologies in a given moment is a function of the collective outcome of hypothesized socio-economic factors. The maximum likelihood method is used to estimate the variables used in the logistic model. Explicitly logistic regression model can be represented as

$$
\mathrm{Y}=\mathrm{b}_{0}+\mathrm{b}_{1} \mathrm{~L}_{1}+\mathrm{b}_{2} \mathrm{~L}_{2}+\mathrm{b}_{3} \mathrm{~L}_{3}+\mathrm{b}_{4} \mathrm{~L}_{4}+\mathrm{b}_{5} \mathrm{~L}_{5}+\mathrm{b}_{6} \mathrm{~L}_{6}+\mathrm{b}_{7} \mathrm{~L}_{7}+\mathrm{b}_{8} \mathrm{~L}_{8}+\mathrm{e}
$$

where $\mathrm{Yi}=$ rate of adoption of cocoyam technology use( percentage)

$\mathrm{L} 1=$ Farm size (Hectare)

$\mathrm{L} 2=$ Age of farmer (Years)

L3 = Education level (Years)

L4 $=$ Extension agents contact in years.

L5 $=$ Access to credit

L6 = Farming experience (Years)

L7 $=$ Household size (No.)

$\mathrm{L}_{8}=$ Off farm income (Naira)

$\mathrm{e}=$ Error term 
Factor analysis was employed to identify the constraints experienced by moringa product marketers, principal component factor analysis with varimax -rotation and factor loading of 0.3 was used. The constraints observed by farmers were grouped into three factors using varimax rotation and factor loading of 0.30 . The principal component factor analysis model is stated thus

$$
\begin{aligned}
& C_{1}=a_{11} f_{1}+a_{12} f_{2}+\ldots+a_{1 n} f_{n} \\
& C_{2}=a_{21} f_{2}+a_{22} f_{2}+\ldots+a_{2 n} f_{n} \\
& C_{3}=a_{31} f_{3}+a_{32} f_{2}+\ldots+a_{3 n} f_{n} \\
& C_{n}=a_{n 1} f_{1}+a_{n 2} f_{2}+\ldots+a_{n n} f_{n}
\end{aligned}
$$

where $\mathrm{C}_{1}=\mathrm{C}_{\mathrm{n}}=$ observed variable/constraints to adoption of adaptation coping strategies to climate change pdts; $a_{1}=a_{n}=$ factor loading or correlating coefficients; $f_{1}=f_{n}=$ unobserved underlying challenging factors facing goat farmers.

\section{Results and Discussion}

Table 1. Definition of Variables Used in the Empirical Analysis

\begin{tabular}{|l|l|l|}
\hline \multicolumn{1}{|c|}{ Variable } & Definition Value/Measure & $\begin{array}{l}\text { Expected } \\
\text { Sign }\end{array}$ \\
\hline Age of household head & Number of years of Head of Household & - \\
\hline Farming experience & Farming experience number of years & + \\
\hline Extension Services & Access to extension services $=1$, otherwise, 0 & + \\
\hline Farming experience & Number of years spent in farming & + \\
\hline Access to Credit & Access to Credit,1; otherwise, 0 & + \\
\hline Educational Level & Number of years of schooling & + \\
\hline Membership of coop & 1=yes and 0=no & + \\
\hline Gender & Male; 1, female, 2, Divorced, 3, Widowed, 4 & - \\
\hline Access to information & (Access $=1$, otherwise=0) & \\
\hline
\end{tabular}

Source, Field Survey, 2017

Table 2 shows that $66.7 \%$ of the respondents were males, while only $33.3 \%$ were females. This implies that males have more management acumen in goat production than females.

Table 2: Distribution of Respondents According to Socioeconomic Characteristics

\begin{tabular}{lll}
\hline Factors & $\begin{array}{l}\text { Frequency } \\
(\mathbf{n = 1 2 0})\end{array}$ & Percentage \\
\hline Gender (dummy) & 80 & \\
Male & 40 & 66.7 \\
Female & & 33.3 \\
Age in Years & 23 & \\
$20-39$ & 51 & 19.2 \\
$30-49$ & 32 & 42.5 \\
$50-69$ & 14 & 26.7 \\
$70-89$ & & 11.7 \\
& & \\
Years of Farming (yrs) & 12 & 10 \\
$1-10$ & 20 & 16.7 \\
$11-20$ & 40 & 33.3 \\
$21-30$ & 32 & 26.7 \\
$31-40$ & &
\end{tabular}


41 and above

Extension contact (dummy)

Had extension contact

No extension contact

Access to Information

Access

No access

Access to Credit Use (dummy)

Yes

No

Membership of Organization (dummy)

Yes

No

Level of Education (Years)

No Formal Education

Primary

Secondary

Tertiary
16

13.3

30

90

68

52

20

100

78

42

10

55

32

23
56.7

16.7

65

35

8.3

25

75

43.3

83.3

45.8

26.7

19.2

\section{Source: Field Survey, 2017}

In addition, most of the respondents (42.5\%) of the respondents were within the age range of 40- 49 years, while the lowest $(19.2 \%)$ were within age range of $20-39$. The implication of the domination of middle aged in goat farming could aid in adoption of innovations in order to forestall the adverse effect of climate change in his/her animal production [23]. More so, all the respondents were experienced in goat production, with the highest (33.3\%) having experienced of $21-30$ years, while the least had $1-10$, representing $10 \%$ of the total respondents. The high number of years of experience will guide for better and rational planning horizon by the farmers in order to put in check the climate change and other environmental effect for high farm animal productivity to ensure [21].

Also, 25\% of the respondents had access to extension services and $75 \%$ had no access. Extension services aid in dissemination of climate change information to farmers in order to curtail maximally the climate change risks [22]. Furthermore, $56.7 \%$ of the respondents had access to information on climate change; only $43.3 \%$ did not have access. Agricultural information could guide farmers in making cogent decisions among alternative goat management practices, so as to ensure rational choice of strategies to be made [26]. Likewise, $83.3 \%$ of the sampled goat farmers had access to credit either from formal, informal sector or both and $36.7 \%$ had access. Credit helps in averting climate change risks by farmers through hiring of labour to be used to accomplish some technologies required in goat production [26]. Moreover, $65 \%$ of the respondents of the respondents are member of organization. Members of the organization could gain access to information patterning to climate change and other environmental effects associated with goat production through interaction among members [29]. Additionally, $91.7 \%$ of the respondents had formal education, while only $8.3 \%$ had no formal education. Educational status of the farmer enhances his / her ease of access to information as regards to climate change and among other environmental effects such as degradation, defforestation etc to goat production[30]. 
The result of the effects of climate change variables on goat production is shown in Table 3 .

Table 3. Distribution of Respondents According to Adaptation Strategies

\begin{tabular}{|l|l|l|}
\hline Adaptation Strategies & Frequency & Percentage (\%) \\
\hline Use of nutrient-dense diets & 78 & 65 \\
\hline Heat resistant roofing material & 72 & 60 \\
\hline Destocking & 85 & 70.8 \\
\hline Extensive rearing & 17 & 14.1 \\
\hline Enough drinking water & 100 & 83.3 \\
\hline Using heat-resistant animal & 65 & 54.12 \\
\hline Planting of tree as shade & 96 & 80 \\
\hline Location of house in the farm & 65 & 54.12 \\
\hline Use of raised Plait-form & 72 & 60 \\
\hline
\end{tabular}

Source: Field Survey, 2017

*Multiple Responses

Shade provision through the use of trees was encountered by $80 \%$ of the respondents. The use of shade is the least-cost alternative and helps to clean air by capturing carbon dioxide and releasing oxygen back into the air for animal use [20]. In addition, $83.3 \%$ of the total respondents opined that they used fresh drinking water Goat production require water for proper digestion and feed utilization [31]. Studies shows that goat is usually has adaptation to limited water availability just like camels [25]. Furthermore, $65 \%$ of the respondents used nutrient - dense diets in checkmating menace of climate change in their goat production. More nutrient-dense diets are usually used to curtail high heat and/or humidity, since animals generate more body heat when they digest poor quality feed [32]. Additionally, $54.1 \%$ of the sampled farmers used east-west orientation of the animal pen, in order to ensure adequate ventilation to reduce accumulation of odour in the animal pen to evade opportunist infestations [22]. Moreover, $60 \%$ of respondents reported use of heat - resistant roofing sheet in animal pen to guide against excessive heat to the animal. The roofing material may be either plain or corrugated galvanized steel sheets or asbestos cement sheets and thatch. Thatched roof is preferred by most poor resource farmers because of its cheaper cost, durability and used where rainfall is not heavy (Wilson, 2004). However, corrugated asbestos sheets can also be used to minimize the recurring costs and to have longer durability [18].

Furthermore, $60 \%$ of the sampled farmers opined that they used raise platform using wood such as planks in making the animal pen floor. This is to guide against possible contamination of pneumonia when the animal lie on the floor, which is common problem of using concrete floor in raising animal during cold season. Furthermore, wood raised plait form importance lies on ease on animal's legs, low maintenance, easy to clean and affordable [32] but poor absorbent of odour as its adverse effect as reported by [14].

Table 4 shows that $75 \%$ of the sampled farmers opined that deforestation could result due to goat production. The increase in livestock grazing land might cause deforestation to low biodiversity.

Table 4. Distribution of Respondents according to effect of Goat Production to the Environment

\begin{tabular}{|l|l|l|}
\hline Variable & Frequency & Percentage \\
\hline Deforestation & 90 & 75 \\
\hline Land degradation & 60 & 50 \\
\hline Climate change & 85 & 70.8 \\
\hline Water waste & 80 & 66.7 \\
\hline Air pollution & 100 & 83.4 \\
\hline Mosquito problem & 75 & 62.5 \\
\hline Rodent menace & 70 & 58.3 \\
\hline Flies problem & 50 & 41.7 \\
\hline
\end{tabular}

Source; Field Survey; 2017 
The deforestation is common in the Amazon basin where for instance about $70 \%$ of earlier forested land is used as pasture, while feed crops is planted in the other remnants [34]. As well, the problem of land Degradation was registered by $50 \%$ of the respondents as a problem associated by goat production. The extensive rearing of goat is common in sub Saharan Africa especially during off farming season. There, animals are allowed to enter the harvested farms to eat up the harvested crop remnant, thus resulting in land degradation. However, the intensity of the land degradation depends on the intensity of the grazing and the flock size $[35,36]$. Also, climate change problem was reported by $70.8 \%$ of the respondents as hitch of goat production to the environs Studies [32] shows that livestock sector, goat inclusive produces carbon dioxide and methane from its manure, which is capable of depleting the ozone layers. The resultant action is the release of heat to the earth, thereby increasing its temperature [32]. The amount of methane emitted by livestock according to [33] depends on flock size, dry matter intake, carbohydrates, and other components of the diet.

Furthermore, $66.7 \%$ of the respondents complained that waste water emanating from processing of goat meat processing. The discharge from goat and livestock in general in the discharge of wastewater containing biodegradable organic compounds (BOC's) into the water bodies resulting in high mortality of aquatic organisms, eutrophication of water bodies caused by Nitrogen and phosphorus leading to casualty of aquatic life due to oxygen reduction and tannins and chromium in tannery effluents; un-ionized ammonia from animal processing have toxic consequence on aquatic life $(34,36]$. Besides, air pollution was posited by $83.4 \%$ of the sampled farmers as cause of goat production to the environments Air pollution may cause varied problems, including global warming,( through release of CO2); reduction of ozone-layer( discharge of $\mathrm{NOx}, \mathrm{CH} 4, \mathrm{~N} 2 \mathrm{O}$ and CFC's) [30], acid rain (emissions of SO2 and NH3) [36] health conditions and dust (from milk powder processing of bone meal) and bad odour from ammonia $\left(\mathrm{NH}_{3}\right)$, volatile organic compounds (VOCs) and hydrogen sulphide $\left(\mathrm{H}_{2} \mathrm{~S}\right)$ [33]. The pungency of such odour may perhaps be a function of the number of times the animal pen is cleaned, velocity of the wind and the moisture nature of the animal manure [9]. Also, dust is another source of air pollution as result of goat rearing. The strength of such dust generated by the animal depends on the goat pen cleanliness, animal activity, temperature, relative humidity, ventilation rate, stocking density, and feeding method $[9,33]$. Additionally, the noise from goat especially when they are hungry and mating could be a form of air pollution. The consequence of that $g$ psychological and possibly physiologic harm to the sufferers [27].

Also, $62.5 \%$ of the respondent complained about mosquitoes. Mosquito breeds in in goat waste especially is damp state, with resultant malaria to the victims of its bite [9]. As well, $41.7 \%$ of the sampled farmers reported on the menaces of cholera, dysentery, typhoid, filarial, and dengue fever to residents of the immediate vicinity where goat is reared. These ailments are transmitted by flies breed in the animal manure [36]. Moreover, $58.3 \%$ of the respondents complained about rodents such as rats breeding. This animal thrives on the stored animal feeds and able to be a threat household effects in the immediate locality [38].

In Table 5, precious feed management was used to checkmate production of methane in the gastric rumen of ruminant in order to evade pollution as posited by $78.4 \%$ of the sampled farmers.

Table 5. Distribution of Respondents According to goat Production Technologies

\begin{tabular}{|l|l|l|}
\hline Variable & Frequency & Percentage (\%) \\
\hline Precious feed management & 95 & 78.2 \\
\hline Litter management & 108 & 90 \\
\hline Use of hydrophilic products & 78 & 65 \\
\hline Rat poison and trap & 87 & 82.5 \\
\hline Adequate housing & 75 & 62.5 \\
\hline proper disposal of animal carcass & 60 & 50 \\
\hline Proper manure disposal & 70 & 58.3 \\
\hline
\end{tabular}

*Multiple responses

Source; Field Survey, 2017 
This could be through increasing the level of grain and lipids, and supplementation with ionophores in the diet (2) feeding maize and cereal silages instead of grass silage, improved pasture management, addition of legumes, yeast and enzyme, feed additives, or plants categorized by secondary compounds with potential $\mathrm{CH}_{4}$ repressing properties [34, 39]. In addition, literatures show that methane digester can be used to curtail methane build up in the animal but studies $[31,33,36]$ indicated that such practice is not very common in most developing countries. Besides, the litter in the goat pen could be managed through use of par formaldehyde and bentonite to guide against environmental pollution through goat production as opined by $90 \%$ of the total respondents. Paraformaldehyde and bentonite according to [30] has bacteriostatic effect on the microorganisms innate in droppings is an efficient plan for curtailing emissions from manure. Litter treatment with paraformaldehyde is capable of manipulating milk hygienic quality, curtailing somatic cell count and microbial cell load of 10 and $15 \%$, respectively [40]. As well, $65 \%$ the use of the hydrophilic products as avenue in abating effect of environmental pollution through goat production. The incorporation or use of hydrophilic products such as hashes, rice husk, peanut husk, dust or sawdust as litters or inside the litter has the capacity of absorbing litter's water content to avoid flies, odour and mosquito building up in goat pen $[34,36]$. Furthermore, $82.5 \%$ of the respondents adopted the technology of use of cat rat poison and trap are often recommended in eradicating rat menace. The proliferation rats in a vicinity is capable of being a threat to the households' effects, as the rat come to eat the domestic or compounded feeds giving to the animal [40].

The Table shows that. $62.5 \%$ of the respondents used proper housing with characteristics features of having adequate ventilation system, good floor design and dust control in control effects of goat production to the environment. The floor of the pen should be concreted with small flushing gutter for ease of cleaning through washing in order to curtail odour maximally [33]. Furthermore, the goat pen should be adequately cleaned, disinfect all the interior surfaces and add oil to goat ration to keep off dust [34]. In addition, $58.3 \%$ of the respondents used proper manure disposal to abate possible air and water pollution as result of goat production. Study [41] revealed prompt removal of manure from goat pen to avert probability of amassing of odour in the pen, which could proliferate to the immediate environment. Furthermore, such manure from the animal pen could be stored in closed storage in form of bags or closed sheds to checkmate odour and prevent flies and mosquitoes breeding in the environs [41]. Finally, $50 \%$ of the respondents used proper disposal of animal carcass through burning, incineration and composting as technique of reducing the effect of goat production to the environment. The improper disposing of goat carcass could predispose the vicinity to air and water pollutions [40].

Table 6 showed that chi-square $\left(\mathrm{X}^{2}\right)(0.3589)$ was highly significant at $1 \%$ level of probability, indicating goodness fit of the model.

Table 6. Determinant Factors to the Adoption of Goat Production related Environmental Technologies

\begin{tabular}{llll}
\hline Variables & Coefficient & Standard Error & t-rate \\
\hline Age & 0.261 & 0.109 & $2.394^{* *}$ \\
level of Education & 0.754 & 0.216 & $3.491^{* * *}$ \\
Extension visit & 0.660 & 0.212 & $3.113^{* * *}$ \\
Off Farm income & 0.1836 & 0.0499 & $2.799^{* *}$ \\
Farming experience & 0.457 & 0.337 & $1.356^{* *}$ \\
Credit access & -0.1501 & 0.1649 & $-0.6676^{* *}$ \\
Membership organization & 0.1753 & 0.1371 & $1.280^{*}$ \\
Access to information & 0.7266 & 0.7402 & 0.9816 \\
Gender & 0.0509 & 0.0624 & 0.9516 \\
$X^{2}$ & $0.3589 * * *$ & & \\
Log likelihood & -168.7705 & & \\
Total sample size & 120 & & \\
\hline
\end{tabular}

Source: Field Survey, 2017

$* * *, * *, *$ are significant levels at $1 \%, 5 \%$ and $10 \%$ respectively. 
The coefficient of age of the farmer was negatively signed, implying that age reduces the desire to adopt technology that has high risk likelihood for instance. This is because most often, high risk projects, often involves massive allocation of material inputs of which the aged may not like to joke with for fear of losing them The finding of [11 was in consistent with the aforementioned affirmation but in divergent with [42] who opined that age of farmer correlates with years of farming experience through exposure to varied experimentations and observation on different technologies, for rational decision on the rightfully choice of technologies to avert fleeting the environs with odour, flies and environmental degradation as result of his/ her goat business. In confirmed with apriori expectation. Statistical test of the coefficient of extension services was positive and significant at $1 \%$ risk level. The above statement concurred to the finding of [42], who attributed that to home and farm visits of the farmer by the extension agents with technologies that not technically feasible, culturally not acceptable and economically not rewarding in solving environmental harms associated with goat production [42]. Extension helps in transferring of knowledge from researchers to farmers and farmers' problem back to research, advising farmers in their decision making, helping farmers in simplify their own goals and possibilities, linking producers to researchers and policy makers and mode of application or usage of the environmental free- technologies on goat production with aim of maximising their output with high regard to environmental sustainability [40].

In addition, a positive and statistically significance is established between the number of years of farming experience and adoption of technology, indicating that the number of years of farming experience of the farmer has the higher propensity of sway his/her adoption decision. Studies [11, 23, 43] shows that years of farming experience enable farmers in setting practical objectives and in surmounting possible degradation of the ecology through their activities in the pursuit to enhance their production and productivity.

As expected, the coefficient of off farm income had direct effect on the prospect of adoption of technology and in harmony with [23] at 95\% confidence level. The finding of [37] concurred with the above affirmation. They reported that that farmers in off farm income has higher odd of having additional income which could be used to purchase modern inputs and hire labour in accomplishment of adoption of technologies with intent of curtailing maximally pollution due to goat production [28]. Besides, statistical test showed that the coefficient of cooperative membership was positive to goat production environmental free technologies and significant at 10\% probability level. Cooperative society helps to have access to member farmers to training and technical assistance on environmental free pollution technologies in goat production. More so, cooperative assists members in procuring genuine inputs to be used in guiding against goat production effect on the environment at appropriate time and affordable prices [11].

More so, the coefficient of level of education had direct relation with adoption of environmental technologies in goat production at $99 \%$ confidence level. This could imply that educated people are often more receptive to adoption of environmental free pollution technologies, as they are aware of the consequences of environmental abuse as result of their activities and could leave nothing to avert it. This may perhaps through adhering to safe use and handling, following manufacturers' instructional manuals on the use of the technologies and wearing all the necessary protective material while applying the technologies [29]. Nevertheless, [8] differed significantly with aforesaid assertion but truly observed that people with high educational status has low probability of being a farmer than engaging in 'white collar job', hence may not be interested in agriculture environmental issues, provided he or she is not directly affected.

The results in Table 8 shows varimax rotated factors militating against goat production in the study area. 
Table 8: Varimax-Rotated Factors Affecting Adoption of the Technology

Constraining Variables Factor 1 Factor 2 Factor 3
\begin{tabular}{|l|l|l|l|}
\hline poor access to extension services & $556^{*}$ & -0.016 & 0.184 \\
\hline Poor Access to Land & 0.135 & 0.023 & 0.217 \\
\hline Poor access Information & $0.361^{*}$ & 0.067 & -0.172 \\
\hline High cost of Labour & 0.463 & 0.218 & 281 \\
\hline Poor access to improved technologies & 0.218 & 0.463 & 0.281 \\
\hline Poor access to heat resistant goat breed & 0.019 & $-0.30 I^{*}$ & 0.142 \\
\hline Poor government intervention & -0.352 & -0.352 & 0.404 \\
\hline No Financial Support & 1.223 & 0.664 & $0.521^{*}$ \\
\hline
\end{tabular}

Source: computed from SAS 2017

Three factors were extracted based on the response of the respondents, Factor $1=$ economic/institutional factor, Factor 2 = infrastructural factor and Factor 3 = socio-financial factor [46]. Only variable with factor loading of 0.30 and above at $10 \%$ overlapping variance were used in naming the factors. This is line with the finding [47] who are of the opinion that varibles with factor loading of less than 0.30 and variables that loaded more than one factor were discarded. Variables that loaded more than one factor like poor government involvement and poor access to land were discovered. .In naming the factors [48] stated that each factor is given a denomination based on the set of variables or characteristics it is composed of. Constraints under the economic /institutional factor include poor access to extension services (0.552), poor access to credit (0.309) and Poor access to information (0.391). This agrees with [17] reported that poor access to credit is one of the major challenges experienced by goat farmers could be linked to among others, inability of the farmers to offer the mandatory collaterals as demanded by the lending agencies. Credit has the potential to enhance efficient resource allocation in order to stem down climate change challenges to goat production [28]. More so, the limited extension services to the farmers in the study area is caused by perhaps, poor motivation of the charge agents and as result most of them develop 'lukewarm' attitude to their jobs [24]. Variables that loaded under factor 2 (infrastructural factor) include; high cost of labour (0.463), poor access to improved technology on climate change (0.497) and poor access to improved goat breeds $(0.301)$. This means that any factor with variable loading of 0.3 and above are the important factor to be considered as serious factor militating against adoption of adaptation coping strategies against climate change in the study area. On poor access to improved technology on climate change, [50] reported that poverty, ignorance of existence of the technology and unavailability or scarcity of the technology could be hindrances to the use or access to a given technology by farmers. On high cost of labour, this could be linked to rural drift of energetic and able bodied youth for 'white collar' job, while the few ones left behind resort to exploit the situation for very high wage charge. Similarly, the finding of [5] and [28] concurred to this assertion. The only variable that loaded under factor 3 (Socio financial factor) that was above 3.0 was no financial support $\left(0.560^{*}\right)$. Farmers complained that no financial support from government and non-governmental organization (NGO), even when goat farms are nearly decimated by effects of climate change elements.

\section{Conclusion and Recommendation}

The result on effect of climate change adaptation on sheep and goat among farmers reveals that males dominated goat production, aged people dominated the farming population and were well educated. Also, the adaptation coping strategies adopted by the farmers were a use of shade, use of nutrient-dense diets, destocking and enough drinking water.

Additionally, the effects of goat production to the environment were deforestation, land degradation, climate change, air pollution and rodent menace. In addition, goat Production Technologies to curtail environmental pollution were precious feed management, litter management, use of hydrophilic products, use of rat poison and trap, adequate housing and proper manure disposal. 
Furthermore, the farmers' socio-economic characteristics that affected the adaptation of climate change coping strategies in sheep and goats production were level of education, farming experience and age of the farmers. The determinant factors to the adoption of goat production-related environmental technologies were level of education, extension visit, off-farm income, farming experience and membership of organization

Finally, the factors limiting farmers' adoption of technology were poor access to credit, poor access to information, poor access to extension services and poor government involvements

Based on the findings, the following recommendations were proffered:

1) Ensure credit access to farmers through microcredit institutions and other financial institutions. Such credit will help farmers to offset costs accruing in purchasing material inputs to be used to abate climate change effects in the farm

2) Extension agents should be adequately motivated and equipped with climate change information in order to aid farmers in abating the negative effect of climate change through information dissemination and technical assistance.

3) There is need to expose the farmers to education programs such as seminars, workshops and adult education, in order to enhance farmers technically with skills and knowledge of averting maximally the effects of climate change in the sheep and goat farmers

4) Experienced farmers should be encouraged to remain in the animals farming by giving them inputs to combat the effects of climate change by appropriate government agencies and non-governmental organizations.

5) Farmers should be encouraged to join or form cooperative to enhance their access to farm inputs at moderate costs and other cooperative services by government agencies concerned

6) The government should persuade farmers to engage in off-farm income since the benefits are enormous through establishing projects in rural areas that have the capacity to employ the farmers of such academic status.

\section{References}

[1] FAO FAOSTAT, statistics division of the food and agriculture organization. http://faostat.fao.org/site/567/desktopdefaultaspx? 2007 Accessed July 03, 2008, Data base results.

[2] C.O.A.I. Albert, A.I. Okidhim, Profitability and challenges of goat production in Etche Local Government Area of Rivers State, Nigeria. Proceedings of international agricultural conferences "ANSUIAC 2012", 6-9 $9^{\text {th }}$ May. Anambra State University, Igbariam Campus, Awka, Anambra State, Nigeria. 2012; P12.

[3] K. Meyer; et al., Productivity potentials of West African Dwarf goats on free range in Kenya. Livestock Prod. Sci., 2010; Pp. 25 -26.

[4] T.A. Adedeji et al., Influence of age and body weight on scrotal lengths and circumference of West African Dwarf bucks in a Cherued savannah environment. Proceedings of 10th Annual conference, Animal Science Association of Nigeria Sept. 12th - 15th Uni: Ado-Ekiti. 2005, 23p

[5] Amaefule, F. O. L, E, Okoye. Seasonal variation in hematological and biochemical profile of red Sokoto and West African dwarf bucks reared in a hot humid environment. Nigerian Agricultural Journal. 2010; 41(2):67-74.

[6] R.T. Wilson, Small Ruminants Production System in tropical Africa. Small Ruminants Res., 1998; 1: $305-325$.

[7] Alamer, Effect of water restriction on lactation performance of Aardi goats under heat stress conditions. Small Ruminants Research, 2009; 84, p.76-81. A.Abdeta, A. Effects of drought on cattle herd dynamics and its implication on local livelihood systems in Borana, Ethiopia. Food Security Center (FSC) Brief No 2011, 1-6. 
[8] S.I. Ume et al., Analysis of the Environmental Effect of Pig Production in Okigwe Local Government Area of Imo State, Nigeria International Journal of Environmental \& Agriculture Research. 1-4(6) (2018).

[9] D.P. Le. Odor from pig production: Its relation to diet. PhD thesis, WIAS, Wageningen, The Netherlands, 2009; 206 pp.

[10] Intergovernmental Panel on Climate Change. (IPCC). Assessment report, volume2, scientific technical analysis of impacts, adaptation and mitigation of climate change, Chaps 13 and 23. In: Watson R. T. Zinyowerw M.C. Moss R.H (Eds.), Cambridge University Press. Cambridge P. $427-$ 467, 745-771.

[11] N. Ozor et al., A Framework for Agricultural Adaptation to Climate Change in Southern Nigeria. A Development Partnerships in Higher Education (DelPHE) 326 Project Executive Summary supported by DFID and implemented by the British Council; Enugu; African Institute for Applied Economics; 2010, 87p.

[12] Abdeta, A. G. Oba. Relating long-term rainfall variability to cattle population dynamics in communal rangelands and a government ranch in southern Ethiopia. Agricultural Systems. 94 (2007) 715-725.

[13] lam et al. Effect of heat stress on behavior, physiological and blood parameters of goat. Progress Agric. 22 (2011) 37-45.

[14] C N. Kandemir et al., Effects of heat stress on physiological traits in sheep. Maced J Anim Sci. 2013; 3(1):25-29.

[15] M. de Rancourt. Mediterranean sheep and goats production: an uncertain future. Small Rumin Res; 2006; 62:167-176.

[16] World Bank, Climate change adaptation in Africa: A Microeconomic Analysis of Livestock choice. World Bank policy research working paper No. 4277, 2007.

[17] B. Mandleni, F.D.K Anim. Climate change awareness and decision on adaptation measures by livestock farmers in South Africa. J Agric Sci 2011; 3(3):258-268

[18] B.K.E Henry et al., Livestock production in a changing .climate: adaptation and mitigation research in Australia. J Crop Past Sci. 63 (2012) 191-202.

[19] A Sidehmed, Livestock and climate change: coping and risk management strategies for a sustainable future in livestock and Global climate change. Conference Proceeding May 2008, Tunisia.

[20] World Bank, Climate change adaptation in Africa: A Microeconomic Analysis of Livestock choice. World Bank policy research working paper No. 4277, 2007; July 2007

[21] C K.Dhakal et al., Determinants of livestock holders' adaptive capacity to climate change in Gandaki River Basin, Nepal. In: Proceedings book of ICEFMO, Malaysia, handbook on the economic, finance and management outlooks,2013; pp 255-263

[22] T T.Deresa et al., Determinants of Farmers' Choice of Adaptation Methods to Climate Change in the Nile Basin of Ethiopia. Global Environmental Change 2009;19: 248-255.

[23] Ozor, N. Y, Cynthia. Climate change and the uncertainties facing communities in the middle belt region of west Africa paper presented at the $7^{\text {th }}$ International Science Conference on the Hunan dimension of global environmental change (IHDP open meeting 2009). held at the United Nation University, Bonn, Germany between 26 April and $1^{\text {st }}$ May. 2010; P 41

[24] T G. Magombo et al., Incidences of indigenous and innovation climate change adaptation practice for small holder farmers livelihoods security in Chikhwawa District, Malawi. Africa Technology Policy study network, Research paper N0.14. 2011.7p 
[25] A A. Aganga, Water utilization by sheep and goats in northern Nigeria. Revista Mundial de Zootecnia, 1992; v.73.

[26] C N. Kandemir et al., Effects of heat stress on physiological traits in sheep. Maced J Anim Sci. 3(1) (2013) 25-29.

[27] NPC. National population Commission sample survey: Abuja, Nigeria, 2006, 8 p.

[28] S.I. Ume, A.I.N. Kaine, Determinants of cocoyam farmers' choice of adaptation methods to climate change in South-East, Nigeria, Journal of Agriculture and Food Environment. 4(2) (2017) 23-35.

[29] S.I. Ume et al., Adoption of Improved Herbicides Spraying Technology among Farmers in Ayamelum L.G.A of Anambra State, Nigeria., Asian Journal of Agricultural Economics, Extension and Rural Sociology. 2016;12(3): 1-7, 2016; Article no. AJAEES.17877.

[30] R. Hassan, C. Nhemachena, Determinants of African Farmers' Strategies for Adapting to Climate Change: Multinomial Choice Analysis. African Journal of Agricultural and Resource Economics, 2008; 2: 83-104.

[31] C. Devendra, G.B. McLeroy, Goat and sheep production in the tropics. ELBS Edn. Longman Singapore, 2012, pp. 20-200.

[32] Mandleni B, F.D.K Anim. Climate change awareness and decision on adaptation measures by livestock farmers in South Africa. J. Agric. Sci. 3(3) (2011) 258-268

[33] Ronchi B, A. Nardone. Contribution of organic farming to increase sustainability of mediterranean small ruminants livestock systems. Livestock Production Science. 80(1-2) (2003) 1731.

[34] S.I. Ume et al., Climate change and Adaptation Coping Strategies among Sheep and Goat Farmers in Ivo Local Government Area of Ebonyi State, Nigeria. Sustainability, Agri, Food and Environmental Research. 2018; 6(2), 50-68.

[35] S. I. Ume, V.E. Uloh, B.E. Nwose. Economic efficiency of goat production in Anambra State of Nigeria. Journal of Science, Agriculture Food Technology and environment. 2(1) (2013) 56-60.

[36] C. Peacock, D.M. Sherman. Sustainable goat production-some global perspectives. Small Rumin Res, 2010; 89:70-80

[37] F.E. Kemausuor et al., Farmers' perception of climate change in the Ejura-Sekyedumase district of Ghana. J Agric Biol Sci.2011; 6:26-37.

[38] H, Steinfeld et al., Livestock and the environment: issues and options. Wrenmedia, Suffolk, U.K., 2014.

[39] D. Fraser, Toward a global perspective on farm animal welfare. Appl Anim Behav Sci. 2008;113: 330-339

[40] M.D. Young, Maintaining Harmony: Equitable and efficient means to minimize negative effects of livestock on the environment. Paper presented in the workshop on Livestock and the Environment, September (2008). World Bank Washington, D.C.2009

[41] S.I. Ume et al., Effect of Climate Variability on Cocoyam Production and Adaptation Coping Strategies by Farmers in Afikpo South Local Government Area of Ebonyi State, Nigeria. Indo - Asian Journal of Multidisciplinary Research (IAJMR). 4(2) (2018) 1387-1395.

[42] S.I. Ume et al., Effect of climate change on pig production and choice of adaptation strategies by farmers in the Southeast, Nigeria. International Journal of Academic Research and Development. $3(2)(2018) 858-868$. 
[43] S.I. Ume et al., Role of Off-Farm Income in Agricultural Production and its Environmental Effect in South East, Nigeria (A Case Study of Commercial Motor Cycle Business), International Letters of Social and Humanistic Sciences. 84 (2018) 1-13.

[44] Mandleni, B. F.D.K, Anim. Perceptions of cattle and sheep farmers on climate change and adaptation in the eastern cape province of south Africa. J Hum Ecol. 34(2) (2011) 107-112.

[45] C. Mustapher, Climate change human security and communal clashes in Nigeria. An international workshop at Holmen Fjored Hotel Asker, near Oslo 21-23 June 2009, P39

[46] A.A. Enete, T.A. Amusa, Determinants of Women's Contributions to Farming Decision Among Cocoa -based Agroforestry Households in Ekiti State, Nigeria FACTS Reports, 4(1). 2010.3p.

[47] G.A. Gbetibouo, Understanding Farmers' Perceptions and Adaptations to Climate Change and Variability: The Case of the Limpopo Basin, South Africa. IFPRI Discussion Paper 00849. Available: http://www.ifpri.org/sites/default/files/publications/rb15_08.pdf.2009

[48] Kanes, R.J. Tobey. An empirical study of the economic effects of climate change on world agriculture. Agron J. 1992;75: 779-788

[49] Ezeano et al., Determinant Factors to Youths Participation in Broilers Production in Imo State of Nigeria. International Journal of Research \& Review; 2017; 4; 1; 345 - 356.

[50] S.I. Ume et al., Effect of Climate Change on Rabbit Production and Choice of Adaptation Coping Strategies by Smallholder Farmers in Anambra State, Nigeria, International Journal of Innovations in Agricultural Sciences. 2(2) (2018) 161-173. 